\title{
Comparative study of cultivation of feces in vermiculite or charcoal to obtain larvae of Strongyloides venezuelensis
}

\author{
Steveen Rios Ribeiro ${ }^{[1]}$, Caroline Ohnesorge Maia ${ }^{[1]}$, Fausto Edmundo Lima Pereira ${ }^{[1]}$ \\ and Narcisa Imaculada Brant Moreira ${ }^{[2]}$
}

[1]. Programa Pós-Graduação em Doenças Infecciosas, Núcleo de Doenças Infecciosas, Universidade Federal de Espírito Santo, Vitória, ES. [2]. Departamento de Patologia, Universidade Federal do Espírito Santo, Vitória, ES.

\begin{abstract}
Introduction: We compared feces culturing in charcoal or vermiculite to obtain Strongyloides venezuelensis larvae. Methods: Feces $(5 \mathrm{~g})$ from infected rats was mixed with vermiculite $(10 \mathrm{~g})$ or coal $(10 \mathrm{~g})$ in plastic cups and incubated at $28^{\circ} \mathrm{C}$ for $48 \mathrm{~h}$. Larvae were recovered using Baermann-Moraes method. Results: Significantly higher number of positive larval cultures were recovered from vermiculite than from charcoal (15/17 and 4/17, respectively; $p<0.001 ; 990.6 \pm 307.5$ and $215 \pm 78.1$ larvae, $\mathrm{p}=0.027)$. Conclusions: Vermiculite yields more larvae and provides cleaner pellets, improving larvae identification and facilitating their use for other purposes.
\end{abstract}

Keywords: Charcoal. Strongyloides. Vermiculite.

Cultivation of stool to obtain helminthic larvae is generally carried out with addition of different substrates or by spreading feces on plates containing solidified agar nutrients ${ }^{1,2}$. The most commonly used culture medium is coal, which must be pure, lacking additives, and, in particular, being free from colloidal silver. Moreover, visualization of the larvae or adult worms is rendered difficult due to the presence of coal particles. Agar culture is laborious and requires appropriate growth medium, adequate glassware, and sterilization systems.

Vermiculite is a compound formed by hydration of basaltic mineral; it has been used as a substrate for fecal culture, particularly in veterinary parasitology, as it has the advantages of being similar to soil and costing less ${ }^{3-7}$. It has also been used for growing insect ${ }^{8}$ or nematodes larvae in order to evaluate the larvicidal effects of fungi ${ }^{9-12}$.

Very few reports have compared the culturing of stools in vermiculite vs. that with addition of other media. Steffan et al. ${ }^{13}$ compared the addition of vermiculite or polystyrene pellets to cultivate cattle feces and found that both significantly improved growth of larvae of Ostertagia ostertagi and Cooperia oncophora as compared to the cultivation of feces without additives.

Agyei ${ }^{14}$ compared the addition of vermiculite or sawdust to cultivate cattle feces to obtain L3 larvae of Haemonchus, Trichostrongylus, Cooperia, and Oesophagostomum and

\footnotetext{
Address to: Dr. Fausto Edmundo Lima Pereira. Núcleo de Doenças Infecciosas/ CCS/UFES. Av. Marechal Campos 1468, 29040-091 Vitória, ES, Brasil.

Phone: 5527 3335-7210

e-mail: felp@ndi.ufes.br

Received 29 January 2014

Accepted 19 May 2014
}

concluded that the number of L3 larvae obtained from sawdust cultures was significantly higher than those obtained by other techniques; the former also did not require further elaborate apparatus.

As there have been no reports comparing the cultivation of feces in vermiculite and charcoal, we here compared vermiculite with charcoal as growth medium for larvae of Strongyloides venezuelensis. Feces of Wistar albino rats infected with S. venezuelensis (900 larvae, subcutaneously) were collected using an anticoprophagic cage. The eggs were quantified with a McMaster chamber. Two identical samples (in terms of weight and eggs per gram) of feces were homogenized with vermiculite (Vermiculite Insulation Thermo-Acoustic Ltd., Belo Horizonte, MG; granulation 1) or coal (Tobasa Bioindustrial, Tocantinópolis, TO; granulation 4) in disposable plastic cups $(200 \mathrm{ml})$ at a ratio of two parts of vermiculite or charcoal to one part stool (e.g., $5 \mathrm{~g}$ of feces and $10 \mathrm{~g}$ of vermiculite or charcoal). The cultures were incubated at $28^{\circ} \mathrm{C}$ for $48 \mathrm{~h}$, and were humidified daily with distilled water. The incubation time was based on the time used for cultivation of feces on coal for recovery of larvae of Strongyloides stercoralis ${ }^{2}$. Larvae were collected from the plastic cups using the Baermann-Moraes technique and counted in one aliquot of $50 \mu \mathrm{L}$. The results of culturing in both media are summarized in Table 1. Of 17 cultures grown in vermiculite, 15 were positive, with recovery of filarial larvae and, exceptionally, free-living forms of the worm. In contrast, among the 17 cultures on coal, only four were positive. The two negative cultures in vermiculite were also negative in coal. When comparing the positive cultures, the mean number of larvae recovered was significantly higher in cultures containing vermiculite (Table 1).

In conclusion, data presented here demonstrated that fecal cultures in the presence of vermiculite, assessed 
TABLE 1 - Comparison of feces culture in vermiculite or charcoal. Feces of rats infected with Strongyloides venezuelensis were mixed with vermiculite or charcoal and incubated at $28^{\circ} \mathrm{C}$ for $48 \mathrm{~h}$.

\begin{tabular}{|c|c|c|c|c|c|}
\hline Culture medium & \multicolumn{2}{|c|}{ Positive/total cultures (17) } & $\mathrm{P}^{*}$ & $\begin{array}{c}\text { Larvae }(\mathrm{n}) * * \\
\text { mean } \pm \mathrm{SD}\end{array}$ & $\mathrm{P} * * *$ \\
\hline Vermiculite & 15 & 88.2 & & $990.6 \pm 307.5$ & \\
\hline Charcoal & 4 & 23.5 & $<0.001$ & $215 \pm 78.1$ & 0.027 \\
\hline
\end{tabular}

*Fisher's exact test; **number of larvae in positive cultures; ***unpaired $t$-test with Welch's correction.

$48 \mathrm{~h}$ after cultivation, yielded significantly better results than cultures grown in the presence of coal, allowing recovery of a larger number of larvae. In addition, the pellet obtained by the Baermann-Moraes method is cleaner, greatly facilitating the identification of larvae and their evolutionary forms, and improving their application for other purposes, such as obtaining antigens and inoculation into experimental animals.

\section{CONFLICT OF INTEREST}

The authors declare that there is no conflict of interest.

\section{REFERENCES}

1. Arakaki T, Iwanaga M, Kinjo F, Saito A, Asato R, Ikeshiro T. Efficacy of agar-plate culture in detection of Strongyloides stercoralis infection. J Parasitol 1990; 76:425-428.

2. Nolan TJ, Megyeri Z, Bhopale VM, Schad GA. Strongyloides stercoralis: the first rodent model for uncomplicated and hyperinfective strongyloidiasis, the Mongolian gerbil (Meriones unguiculatus). J Infect Dis 1993; 168:1479-1484.

3. Ogunsusi RA. Evaluation of oxfendazole against natural infections of gastrointestinal nematodes in Nigerian calves. Res Vet Sci 1979; 27:246-247.

4. Fossing EC, Knudsen TS, Bjørn H, Nansen P. Development of the freeliving stages of Hyostrongylus rubidus and Oesophagostomum spp. at different temperatures and humidities. J Helminthol 1995; 69:7-11.

5. van Wyk JA, Cabaret J, Michael LM. Morphological identification of nematode larvae of small ruminants and cattle simplified. Vet Parasitol 2004; 119:277-306.
6. van Lieshout L, de Gruijter JM, Adu-Nsiah M, Haizel M, Verweij JJ, Brienen EA, Gasser RB, Polderman AM. Oesophagostomum bifurcum in non-human primates is not a potential reservoir for human infection in Ghana. Trop Med Int Health 2005; 10:1315-1320.

7. Fernandes A, Pereira AT, Eschenazi PD, Schilter HC, Sousa AL, Teixeira MM, et al. Evaluation of the immune response against Strongyloides venezuelensis in antigen-immunized or previously infected mice. Parasite Immunol 2008; 30:139-149.

8. Boardman LA. Insectary culture of Spodoptera litura (Lepidoptera: Noctuidae). N Z Entomol 1977; 6:316-318.

9. Terrill TH, Larsen M, Samples O, Husted S, Miller JE, Kaplan RM, et al. Capability of the nematode-trapping fungus Duddingtonia flagrans to reduce infective larvae of gastrointestinal nematodes in goat feces in the southeastern United States: dose titration and dose time interval studies. Vet Parasitol 2004; 120:285-296.

10. Campos AK, Araújo JV, Guimarães MP. Interaction between the nematophagous fungus Duddingtonia flagrans and infective larvae of Haemonchus contortus (Nematoda: Trichostrongyloidea). J Helminthol 2008; 82:337-341.

11. Carvalho RO, Araújo JV, Braga FR, Araujo JM, Silva AR, Tavela AO. Predatory activity of nematophagous fungi on infective larvae of Ancylostoma sp.: evaluation in vitro and after passing through the gastrointestinal tract of dogs. J Helminthol 2009; 83:231-236.

12. Araujo JM, Araújo JV, Braga FR, Carvalho RO. In vitro predatory activity of nematophagous fungi and after passing through gastrointestinal tract of equine on infective larvae of Strongyloides westeri. Parasitol Res 2010; 107:103-108.

13. Steffan P, Henriksen SA, Nansen P. A comparison of two methods and two additives for faecal cultivation of bovine trichostrongyle larvae. Vet Parasitol 1989; 31:269-273.

14. Agyei AD. An improved method of using sawdust as a faecal culture medium for the production of 3rd stage strongylate nematode larvae. Ghana Jnl Agric 1995; 28-29:11-15. 